Check for updates

UCL Institute of Health Equity, UCL

Twitter: @MichaelMarmot

Cite this as: BMJ 2022;376:0356

http://dx.doi.org/10.1136/bmj.0356

Published: 10 February 2022

\section{The government's levelling up plan: a missed opportunity}

\section{Government policies from $\mathbf{2 0 1 0}$ have increased the slope rather than levelled up. It is time to reverse course, writes Michael Marmot}

\section{Michael Marmot professor and director}

"Bliss it was in that dawn to be alive but to be young was very heaven.” Wordsworth may have moved from the lakes in the North of England to France by the time he wrote Book 10 of The Prelude but, then as now, bliss is unevenly distributed in Britain and the heavenly nature of being young depends a great deal on where in the country you live. Being young in the North of England-“north" being from the Midlands on up-means life chances are a good deal worse than being young in the South. ${ }^{1}$ Risk of death at most ages is greater; over the decade from 2010 onwards the health disadvantage in the North grew bigger; and it got worse again with covid-19. ${ }^{2-4}$

A particular challenge to improving health is that, in general, health inequalities are bigger in the North-East and the North-West than they are in London and the South-East. Classify people by where they live and classify where they live by the Index of Multiple Deprivation and we find, for people living in the least deprived decile, there is little regional variation in life expectancy. If you're rich it matters little in which region you live. But the greater the deprivation, the greater the health disadvantage of living in the North. Or, to describe the same data differently, the social gradient in life expectancy is steeper in the North than in London and the South-East. It has been thus at least since the 1970 .

In the decade following 2010, the life expectancy gradient in the North grew steeper still. Worse, life expectancy for the poorest decile declined in the North East, Yorkshire, and Humber. Years spent in ill health increased. ${ }^{3}$ Our several reports from the UCL Institute of Health Equity, and others, make clear that these health inequalities are not primarily a healthcare issue, but have much to do with the social determinants of health: the conditions in which people are born, grow, live, work, and age; and the structural drivers of those conditions:

macroeconomic, environmental, and the structure of society, including institutional racism. ${ }^{5}$ It is likely, based on the evidence, that a decade of austerity and rolling back of the state from 2010 on, is the root cause of this worsening health situation. ${ }^{3}$ Arguably, government policies from 2010 to 2020 increased the slope-and so sloped up, rather than levelled up.

It is time to reverse course. Levelling $U p$, the much awaited government white paper, sets out the diagnosis of the problem and what needs to be done. There is much that is good in the white paper's 332 pages. It has four objectives for deprived parts of the country: boost productivity, pay, jobs, and living standards; spread opportunity and improve public services; restore a sense of community and local pride; empower local leaders and communities. Can't argue with any of that, particularly giving powers to metropolitan Mayors. If those objectives were achieved it is highly likely that inequalities in healthy life expectancy would be reduced. The white paper then sets out 12 missions that cover: living standards, transport, research and development, digital connectivity, education, skills, health, wellbeing, pride in place, housing, crime, and local leadership. What's not to like? Achieve the other 11 missions and health equity will improve.

The problem is that this white paper reads as though it was not the product of a political party that has been in power in Britain for 30 of the last 43 years and is responsible for much of the damage.

Manchester was the home of the industrial revolution, but the widespread de-industrialisation of the $1980 \mathrm{os}$ wreaked economic havoc on the North and tore at the heart of communities. The rise of the service sector contributed to the prosperity of London, but did little for the North. Further, the austerity policies of the governments from 2010 onwards caused more hardship. Public sector expenditure fell, child poverty rose, there were sharply regressive changes to tax and benefits. Latest figures from the Food Foundation show that $8.8 \%$ of households -4.7 million adults-experienced food insecurity in the last month. ${ }^{6}$ In the context of levelling up, the post 2010 cuts to local government are really telling-the more deprived the area, the steeper the cuts. It has been estimated that cuts to local government in the North amounted to $£ 413$ per person. ${ }^{7}$ By contrast the 2021 allocation from the levelling up fund amounts to $£ 32$ per person in the North.

The government could argue that they want to make a fresh start, but the allocations thus far show that their ambition is not yet equal to the task. The 2021-24 allocation of levelling up funds, according to the white paper, is $£ 4.8$ billion. The white paper draws attention to what Germany spent to "level up" when Eastern Germany, the former German Democratic Republic, joined the Federal Republic: $€ 2$ trillion over 25 years; about $€ 70$ billion a year.

If the current $£ 4.8$ billion is a taster, a start, and the white paper represents a whole scale rejigging of government, with resources on the scale of Germany's levelling up, then the objectives and missions are exactly what is needed. If, as the Chancellor of the Exchequer has made clear, the regressive cuts to public expenditure will not be reversed and, when he can, he is more interested in cutting taxes than levelling up, we can expect health inequalities to continue. A missed opportunity. 


\section{OPINION}

Competing interests: MM was the senior author of the UCL Institute of Health Equity publications: Health Equity in England: the Marmot Review 10 Years On and Build Back Fairer, both of which were funded by the Health Foundation.

Provenance and peer review: commissioned, not peer reviewed

1 Pickett K. T-RD, et al The Child of the North: Building a fairer future after COVID-19,. 2021.

2 Buchan IE, Kontopantelis E, Sperrin T, Chandola T, Doran T. North-South disparities in English mortality 1965-2015: longitudinal population study. J Epid Comm Health, 2017, doi: 10.1136/jech-2017-209195:1-9.

3 Marmot M, Allen J, Boyce T, Goldblatt P, Morrison J. Health Equity in England: The Marmot Review 10 Years On. Institute of Health Equity, UCL, 2020.

4 Marmot M, Allen J, Goldblatt P, Herd E, Morrison J. Build Back Fairer: The COVID-19 Marmot Review. The Pandemic, Socioeconomic and Health Inequalities in England. Institute of Health Equity, 2020.

5 Due North WM. The report of the Inquiry on Health Equity for the North. 2014

6 The Food Foundation. New data shows food insecurity major challenge to levelling up agenda. February 2022. https://foodfoundation.org.uk/press-release/new-data-shows-food-insecuritymajor-challenge-levelling-agenda

7 The IPPR. Exposed: The gap between levelling up rhetoric and reality. https://www.ippr.org/newsand-media/press-releases/exposed-the-gap-between-levelling-up-rhetoric-and-reality 